\title{
The Impact of Sociodemographic and Health Variables on Self-Care of Subjects Receiving Hemotransfusion
}

\author{
Sueli Mendes de Oliveira ${ }^{1}$, Enéas Rangel Teixeira ${ }^{2}$, Eliane Ramos Pereira ${ }^{2}$, \\ Josélia Braz dos Santos Ferreira ${ }^{1,3}$, Sandra Regina Terra Campos Nicolau${ }^{1}$, \\ Jovíria Márcia Ferreira de Oliveira Padilha ${ }^{1}$ \\ ${ }^{1}$ Antônio Pedro University Hospital, Niterói, RJ, Brazil \\ ${ }^{2}$ Aurora de Afonso Costa Nursing School of the Fluminense Federal University, Niterói, RJ, Brazil \\ ${ }^{3}$ Miguel Pedro Municipal Hospital of Geriatrics and Gerontology, Rio de Janeiro, Brazil \\ Email: suelimendesdeoliveira@gmail.com, eneaspsi@hotmail.com, elianeramos.uff@gmail.com, joseliabraz42@yahoo.com.br, \\ srtcn@hotmail.com, joviria@ibest.com.br
}

How to cite this paper: Oliveira, S.M.de, Teixeira, E.R., Pereira, E.R., Ferreira, J.B. dos S., Nicolau, S.R.T.C. and Padilha, J.M.F. de O. (2017) The Impact of Sociodemographic and Health Variables on Self-Care of Subjects Receiving Hemotransfusion. Open Journal of Nursing, 7, 294-306. https://doi.org/10.4236/ojn.2017.72024

Received: January 3, 2017

Accepted: February 25, 2017

Published: February 28, 2017

Copyright (๑) 2017 by authors and Scientific Research Publishing Inc. This work is licensed under the Creative Commons Attribution International License (CC BY 4.0).

http://creativecommons.org/licenses/by/4.0/ (c) (i) Open Access

\begin{abstract}
This study analyzed the relationship between self-care in subjects who received a blood transfusion in a university hospital with their sociodemographic and health conditions. A descriptive and exploratory research with a qualitative approach was carried out in the Transfusion Ambulatory sector of the University Hospital in Niterói, Rio de Janeiro from July to November of 2014 with a sample size of 12 patients. Data were collected through a questionnaire of semi-structured questions; content analysis was based on the thematic approach. Sociodemographic data from subjects who received a blood transfusion were evaluated with respect to the education they received regarding self-care at home as well as their emotional balance in facing the health-disease process and their perspective on their quality of life. Educating subjects who receive blood transfusions requires that the medical professionals have an understanding of their patient's socioeconomic and cultural condition. This information will contribute to a better understanding of self-care when blood transfusion is necessary.
\end{abstract}

\section{Keywords}

Hemotherapy Service, Blood Transfusion, Nursing Care, Health Education

\section{Introduction}

Transfusion therapy is indispensable in health practice because it reduces mor- 
tality, prolonging and improving the quality of life of patients who present with a variety of clinical conditions. The correction of anemia resulting from various causes, and blood replacement in complex surgical procedures as well as hematological and oncologic diseases, are among the benefits of this procedure. However, transfusions are not free from risks fatalities [1].

Although hemotherapy services perform strict control over their products, risks related to production, storage, the release of serology profiles, and preparation of blood components still exist. It is important to identify these risks and to implement safety techniques such as indicators, adverse event monitoring, and audits to reduce or prevent adverse events [2].

Because hemotherapy is a health specialty that depends on specific scientific and technical knowledge, the inclusion of hemotherapy content in nursing courses and related areas is important: therefore, future professionals can provide safe assistance before, during, and after the transfusion of blood components, which is a specific procedure. It is fundamental to know how to recognize a transfusion reaction, and thus, provide quality care to these patients.

The presence of professionals with specific knowledge in this area of performance has become fundamental. Since the 1990s, the role of nursing in hemotherapy has undergone several changes to keep up with the evolution of hemotherapy. New protocols were necessary to not only comply with legal requirements, but also to regularize various activities, provide quality service, and minimize risks and complications in all stages of the blood cycle [3] [4].

Resolution No. 306/2006 of the Federal Nursing Council (COFEN) defines the competencies and duties of the hemotherapy nurse in article 1 . These responsibilities include, but are not limited to, fully assisting donors and recipients and their families; promoting preventive, educational, and curative actions among recipients, family members, and donors; performing clinical triage for the evaluation of donors and recipients; and implementing actions related to the supervision and control of the nursing team [5].

In the United States (USA) as well as in other countries, the increase in blood transfusions results from changes in the population demographics and technological advances of procedures, hence the need for an increased number of donations [6]. It is assumed that 22 million transfusions will occur on average in one year; despite improved hemotherapy protocols, about $20 \%$ of subjects receiving transfusions show adverse effects of varying clinical severity. This statistic has adverse implications for health and logistics on administrative and economic bases [7].

According to the World Health Organization (WHO) [8], 18\% of red cells are used for trauma in developing countries while $7 \%$ is used in developed countries.

In order to protect donors and recipients, the Brazilian Ministry of Health (MS) in the Resolution of Collegial Direction-RDC 57 of December 17, 2010 by ANVISA established minimum requirements for services that perform activities related to the blood production cycle, from collection to transfusion. Ordinance MS no. 1353 of June 13, 2011 approved the Technical Regulation for Hemothe- 
rapeutic Procedures (RTPH) in accordance with the principles and guidelines of the National Blood Policy [9]. Ordinance $\mathrm{n}^{\circ} 2712$ of November 12, 2013 redefined this regulation [1].

In Brazil, the donation of blood is voluntary, anonymous, altruistic, and unpaid. Donor anonymity means ensuring that recipients do not identify the donor of the blood received or that donors do not identify recipients, except in technically justified situations [10]. In 2013, the MS reduced the minimum age of donors from 18 to 16 years (with the consent of guardians) and increased the maximum donor age to 69 years; the maximum age for the first donation is set at 60 years in order to increase the number of new volunteers to 8.7 million [1].

Nurses who deal with the entire blood cycle process perform complex and sensitive work such as clinical screening of blood donors, nursing consultation to donors with positive serology, guidance to family members with due referrals for treatment, organization of teamwork, and transfusion of blood components. They must also cope with adverse transfusion reactions which may occur during or after therapy. A well trained and qualified hemotherapy nursing team should provide a safer and more efficient transfusion process [11].

The nurse is responsible for assisting the patient, valuing him as an individual, and offering preventive, curative, and rehabilitative care so that the patient may actively participate in his care as fully as possible.

The term self-care was first mentioned in 1958 when nurse Dorothea Elisabeth realized patients needed to take care of themselves and required guidance to achieve self-care. This realization resulted in the development of the general nursing theory of self-care deficit. The practice of self-care requires the patient's realization that they have the aptitude and ability to self-care, and may contribute to improving their quality of life [12].

Training nurses to effectively educate subjects in self-care is important to achieving the quality of life for the patient. Thus, in order to develop educational practices for nurses which are directed to a patient's specific needs, this study analyzed the self-care of university hospital patients who received blood transfusions with respect to their sociodemographic and health conditions.

\section{Method}

This was a descriptive and exploratory study with a qualitative approach. The sample consisted of 12 subjects. Data were collected from July to November of 2014 in the Ambulatory Transfusion section, which is part of the Hemocenterat the Antônio Pedro University Hospital of the Fluminense Federal University located in Niterói, Rio de Janeiro, Brazil (HUAP/UFF/Niterói/RJ). HUAP is a well-regarded teaching and research institution; it belongs to the federal public network linked to the Ministry of Education and the Unified Health System (SUS) hierarchy at the tertiary and quaternary levels. It operates 24 hours a day, however, the ambulatory service providing assistance with transfusion therapy and therapeutic bleeding closes at $7 \mathrm{pm}$.

The subjects recruited for this study were mainly from the Hematology and 
Oncology outpatient clinic and most had diagnoses of Lymphoma, Leukemias, Myelodysplasia, HIV, Multiple Myeloma, Myofibrosis, and other types of cancer; some of these clients were in palliative care. The average number of monthly outpatient transfusions is 70 .

The nursing team that works in the Transfusion Ambulatory sector consists of one attending nurse and one nurse Coordinator, eleven nursing technicians and assistants, and two hemotherapist physicians.

The content analysis was based on the thematic of Bardin [13] and considered the theme as the main element, which can be represented by a word, phrase, or summary. It consists in discovering the nuclei of meaning that make up the communication and whose presence or frequency of appearance in the messages, texts, or speeches might have a meaning for analysis according to the objective. The inclusion criteria were subjects who received an outpatient blood transfusion and were over 18 years of age at the time of data collection. The exclusion criteria were subjects who experienced an adverse event during the transfusional or demonstrated some limitation during the interview that made the comprehension such as difficulty speaking, impaired visual acuity, or hearing loss. All participants signed the Free and Informed Consent Form (TCLE) and agreed to participate in the study before starting the study. Subjects were interviewed before and/or during the transfusion therapy. The socio-demographic data obtained in the interview were recorded in a questionnaire with semistructured questions by the researcher.

The study was approved by the Ethics Committee on Research involving Human Beings of the School of Medicine of the Fluminense Federal University/ FM/UFF/HUAP under No. 608875 in 2014 . The ethical precepts of voluntary and consensual participation were respected. The study did not lead to risks or physical, economic, or social damages to participants.

\section{Results}

The study involved 12 individuals, 50\% men and 50\% women (Table 1 and Table 2). The age range in the sample was from 25 to 73 years, with an average of 56.75 years; $75 \%$ was in the range between 50 and 73 years old. The diseases presented in Table 1, which are individualized, correspond to the participants in this study in which the diagnoses of Myelodysplasia and Multiple Myeloma were predominant, both with $16.7 \%$; $66.7 \%$ of participants used the health services of the Hospital University only; $75 \%$ had education equivalent to incomplete middle school; $75 \%$ declared themselves as white, $66.7 \%$ were Catholics, $33.3 \%$ were married, $25 \%$ were widows; and $25 \%$ were unmarried. A total of $50 \%$ were retired with a monthly income between one and three Brazilian minimum wages (83.30\%).

All participants lived in urban areas, $75 \%$ in houses; of these, 50\% lived with two other persons; $91.7 \%$ of clients used only water provided by the water supply distribution network, however, one client also used water from an artesian well. All participants stated having basic sanitation and garbage collection in their 
Table 1. Sociodemographic data of the Participants of the research according to Gender, Age range, Diagnoses and Blood transfusion, University Hospital Ambulatory, Niterói, Rio de Janeiro, 2014.

\begin{tabular}{|c|c|c|c|c|}
\hline Participants & Gender & Age range & Diagnoses & Blood transfusion \\
\hline Participant 1 & Female & 25 & Lymphoma & Red blood cells concentrate \\
\hline Participant 2 & Female & 57 & Lymphoma + HIV & Platelets + hematocrit concentrate \\
\hline Participant 3 & Male & 71 & Myelodysplasia & Red blood cells concentrate \\
\hline Participant 4 & Female & 32 & Anemia to be clarified & Platelets + hematocrit concentrate \\
\hline Participant 5 & Female & 73 & MultipleMyeloma & Red blood cells concentrate \\
\hline Participant 6 & Male & 71 & Myofibrosis & Red blood cells concentrate \\
\hline Participant 7 & Female & 56 & Multiple Myeloma & Red blood cells concentrate \\
\hline Participant 8 & Male & 66 & \multicolumn{2}{|c|}{ Plaquetopenia to be clarified Platelets + hematocrit concentrate } \\
\hline Participant 9 & Male & 64 & Oropharyngeal cancer & Red blood cells concentrate \\
\hline Participant 10 & Female & 43 & Sickle cell anemia & Red blood cells concentrate \\
\hline Participant 11 & Male & 60 & Lung cancer & Red blood cells concentrate \\
\hline Participant 12 & Male & 63 & Myelodysplasia & Red blood cells concentrate \\
\hline
\end{tabular}

Source: Data from the research, 2014.

homes.

The sociodemographic and health conditions factors shown in Table 1 and Table 2, which affect self-care, are correlated because $75 \%$ of participants have low levels of education with incomplete elementary education, that is, they are only literate, and therefore, have difficulty in understanding the guidelines given by nurses, which hampers the adequate self-care directed to the health problems presented, aggravated by the conditions of precarious housing and low wages. These conditions are insufficient to their survival and interfere in their social life such as difficulties related to transportation, feeding, acquisition of medication, and adherence to treatment.

In Table 1, follow the data according to interviews performed at the University Hospital.

These data are in agreement with the literature in relation to age, marital status, education, occupation, income, and disease occurrences; the majority (75\%) was between 50 and 73 years old, $75 \%$ had incomplete elementary and middle school, 50\% were retired, $25 \%$ were housewives, and $83.30 \%$ received between 01 and 03 Brazilian minimum wages and were under treatment due to illness. All reported following some type of religion.

Each blood bag has an average of $300 \mathrm{ml}$ in the hemotransfusion in the outpatient clinic; sometimes plasma is needed and sometimes platelets are needed. Most of the time, each client receives $300 \mathrm{ml}$ of transfusion. It occurs that, sometimes patients (25\%) need a larger volume of blood components, which requires 
Table 2. Sociodemographic aspects of clients submitted to blood transfusion at the University Hospital Ambulatory, Niterói, Rio de Janeiro, 2014.

\begin{tabular}{|c|c|c|c|}
\hline Variables & Specifications & $\mathrm{n}=12$ & $\%$ \\
\hline \multirow{2}{*}{ Gender } & Female & 6 & 50 \\
\hline & Male & 6 & 50 \\
\hline \multirow{2}{*}{ Hemotransfusion } & 1 bag & 9 & 75 \\
\hline & 2 bags & 3 & 25 \\
\hline \multirow{3}{*}{ Age range } & 18 to 29 years & 1 & 8.3 \\
\hline & 30 to 49 years & 2 & 16.7 \\
\hline & 50 to 73 years & 9 & 75 \\
\hline \multirow{10}{*}{ Diagnoses } & Lymphoma & 1 & 8.3 \\
\hline & Lymphoma + HIV & 1 & 8.3 \\
\hline & Myelodysplasia & 2 & 16.8 \\
\hline & Multiple Myeloma & 2 & 16.8 \\
\hline & Myofibrosis & 1 & 8.3 \\
\hline & Plaquetopenia to be clarified & 1 & 8.3 \\
\hline & Oropharyngeal cancer & 1 & 8.3 \\
\hline & Sickle cell anemia & 1 & 8.3 \\
\hline & Lung cancer & 1 & 8.3 \\
\hline & Anemia to be clarified & 1 & 8.3 \\
\hline \multirow[b]{2}{*}{ Health Services } & Uses only the University Hospital & 8 & 66.7 \\
\hline & $\begin{array}{l}\text { Uses basic healthcare units and private } \\
\text { services at popular prices }\end{array}$ & 4 & 33.3 \\
\hline \multirow{3}{*}{ Education } & Incomplete elementary and middle school & 9 & 75 \\
\hline & Complete elementary and middle school & 1 & 8.3 \\
\hline & Complete High School & 2 & 16.7 \\
\hline \multirow{3}{*}{ Race } & White & 9 & 75 \\
\hline & Black & 2 & 16.7 \\
\hline & Brown & 1 & 8.3 \\
\hline \multirow{3}{*}{ Religion } & Catholic & 8 & 66.7 \\
\hline & Evangelical & 3 & 25 \\
\hline & Espiritual & 1 & 8.3 \\
\hline \multirow{4}{*}{ Marital Status } & Singles & 3 & 25 \\
\hline & Widowers & 3 & 25 \\
\hline & Married & 4 & 33.3 \\
\hline & Divorced & 2 & 16.7 \\
\hline \multirow{4}{*}{ Occupation } & Retired & 6 & 50 \\
\hline & Housewife & 3 & 25 \\
\hline & Self-employed & 2 & 16.7 \\
\hline & Administrative assistant & 1 & 8.3 \\
\hline \multirow{2}{*}{ Income } & 0 & 2 & 16.7 \\
\hline & 1 to 3 & 10 & 83.3 \\
\hline \multirow{2}{*}{$\begin{array}{l}\text { Housing/poor } \\
\text { neighborhoods in } \\
\text { Niterói }\end{array}$} & House & 9 & 75 \\
\hline & Apartment & 3 & 25 \\
\hline \multirow{4}{*}{ Household } & Live alone & 3 & 25 \\
\hline & Two people & 2 & 16.7 \\
\hline & Three people & 6 & 50 \\
\hline & Twelve people & 1 & 8.3 \\
\hline \multirow{2}{*}{ Water supply } & Network water supply & 11 & 91.7 \\
\hline & Water from a well & 1 & 8.3 \\
\hline
\end{tabular}

Source: Data from the research, 2014. 
more than one blood bag, and thus they receive two hemotransfusion bags in the same day at the most and according to their health and age. If necessary, the doctor plans another transfusion in another day.

One of the limitations of this study is related to the size of studied sample because only 12 clients met the inclusion criteria. However, this contribution is fundamental considering the growth of the elder population [14]. Therefore, it is suggested that other studies be carried out with larger populations of clients in hemotransfusion, aiming at improving their quality of life.

\section{Discussion}

In this study, the same number of women and men was observed among participants, however, in other studies women predominate [14].

Our epidemiological results are in agreement with the statistical data from the National Cancer Institute (INCA) which shows that the incidence of cancer occurs mainly in clients over 40 years old with a low level of education and low monthly income. The low level of education prevents access to understanding prevention and early detection of diseases, and increases the difficulty of accessing health services linked to the SUS. Beliefs and distorted perceptions about diseases on the part of poor people with lower levels of education are also factors that can contribute to a delay in obtaining health services and lead to the diagnosis of advanced stage neoplasms [14].

Thus, an individual needs to understand some basic information in order to manage his health condition. However, knowledge alone is not sufficient to promote behavioral change, a change which involves other variables such as education, time since diagnosis, health and illness beliefs, family support, and ease of access to health services. Studies have pointed out the importance of spouses or other family members to individuals with life-threatening illnesses: the greater emotional support provided improve the chances of adapting to lifethreatening illnesses and the stress caused by them [15] corroborating the data in this study because the majority were married (33.3\%) and 50\% live in the company of other people.

Although there is a possibility of cure when diagnosed early and interrupted in one of its phases, neoplasia is one of the most feared chronic-degenerative diseases, involving multiple risk factors such as environmental, lifestyle, and genetics. According to some studies [16], the occurrence of these conditions has increased over the decades and have more frequently been associated with age. All interviewees in this study live in urban areas. Urbanization and industrialization contribute to environmental risk factors and socioeconomic inequalities, to which about $80 \%$ of cases of cancer are attributed [17].

Some authors have noted the large number of elderly people who are diagnosed late, making treatment difficult [18]. Late diagnoses may be due to a poor understanding on the part of the medical professional of how to effectively communicate with elderly patients. Another reason is the scarcity of studies and publications in the area of oncogeriatry, mainly at the national level. 
The term "health" is related to the historical-cultural changes in the evolution of man and his organizations due to social, economic, cultural, and political interferences of a given social organization. In this research, $66.7 \%$ of the clients use only the University Hospital as health services. Therefore, a set of conditions, goods, and services used by individuals according to their behavior patterns is considered healthy, and therefore, they constitute parameters of normality according to their way of living in a given society aiming for autonomy and improved quality of life [19].

The testimonies of these clients showed the concepts of health that are necessary to maintain life through expressions of functionality related to roles such as working, walking, practicing physical activities, and enjoying the quality of life despite the illness. The quality of life is related to self-esteem and personal wellbeing covering a number of aspects such as functional capacity, socioeconomic level, emotional state, social interaction, intellectual activity, self-care, family support, health status, and cultural, ethical, and religious values. It also includes lifestyle, job satisfaction and/or satisfaction with daily activities, and the environment in which one lives [20].

As for religiosity, spirituality, or religious beliefs, it can benefit families as a means of coping, social and emotional support, and hope during stressful situations experienced in cases of illness and possibility of death. An individual's spirituality may contribute to hope and optimism and allow the person to face the stress resulting from illness in a more positive way [21] [22]. Some studies indicate that religious communities usually provide support ranging from interaction and social support to contribution in tasks, finances, and transportation, to patients with oncological diseases [21].

Most of the patients who require ambulatory transfusions are accompanied by relatives and/or friends who demonstrate anxiety and concern through facial expressions and questions about transfusion; they sometimes arrive quite physically and emotionally debilitated, particularly during the first few transfusions. Certain clients reported symptoms such as fever, pruritus, and urticaria occurring at home and after the transfusion.

Discussions with subjects who received a blood transfusion, provided an understanding of factors that contribute to the improvement in the quality of nursing care in this setting, and demonstrated the importance of guidelines for the care that should be provided to subjects to ensure they receive an integral and planned assistance. Care guidelines should include subject-based health education that encourages the process of awareness and attention to self-care, especially at home. This fact allowed us to reflect on possible late transfusion reactions that were not being detected or adequately treated at the level of the subject's condition. Thus, health education activities must be focused on the client's needs, aiming at self-care in order to reduce possible complications.

Societies have different discourses about health/illness and about the body, which usually reflects a worldview and social reality. It is possible to perceive the relationship between the way of living, getting sick and dying, and social condi- 
tions, which allows us to relate living conditions, habits, and illness.

Therefore, health is a reflection of the country's political re-democratization environment and, above all, of the strength of the health movement in the struggle for the expansion of social rights: "Health is the right of all and a duty of the State, guaranteed through social and economic policies, reducing risks of diseases and other illnesses, and equal universal access to actions and services for health promotion, protection, and recovery", as recommended by WHO. The greatest merit of this concept is the clarification of the social determinants of health and disease, aspects often neglected in models that favor individual and sub-individual approaches [23]. In order to alleviate these problems, the State should guarantee the right of the population to quality medical services, which provide diagnosis and treatment.

Cancer is one of the diseases most feared by patients, family members, and close friends, who most often struggle with negative feelings such as fear of diagnosis, fear of treatment and side effects, the uncertainty of prognosis, and especially fear of pain and the possibility of death [21]. These emotions were corroborated by the subjects who participated in this study.

Changes due to on co-hematological diseases may compromise independence and autonomy in the elderly, leading to limitations for the establishment of self-care. These limitations include knowledge about the disease, motivation and capacity to face the diagnosis, and incentive to continue the treatment proposed by the health team [22].

Thus, the educational practice focused on self-care for the elderly patient may favor emphasizing coping and adaptation as an effective alternative to education. Considering education as an important instrument, Orem advocated raising awareness in the individual through reflection on reality and by encouraging participation in the decision-making process. The more aware the client, the better he will cope with his reality. Working to engage the patient in the decision-making process is an extremely important task for the nurse. Having a fully engaged patient facilitates the success of self-care through a horizontal educational, dialogic, and participatory work. These care activities are related to individual habits of life, customs, rituals, and beliefs, and are related to the way in which these individuals assimilate and use the resources available in their environments [24].

Understanding the patient as an individual with doubts, curiosities, and knowledge resulting from community practice should be the first step towards the establishment of a progressive educational practice To think of the patient as a person without the understanding and ability to decide about his actions or expand and transform his knowledge is a thing of the past [25].

Health education is more than just curative assistance, and includes prioritizing preventive and promotional actions, understanding the socioeconomic status of the users of health services, stimulating them to fight for more dignity and increasing g quality of life. In this context, health education aims to guarantee the dignity of people through the promotion of health, fundamental human rights, 
self-determination, and responsibility for life itself with a view to their existence and human needs [26].

Nurses and other health professionals play an important role in this activity showing alternatives to healthy habits, social integration, and independence in daily activities, which can improve the health of clients, families, and the population in general.

Therefore, the necessary interventions for health promotion should be centered on collective work and guaranteed through social policies aimed at individuals and communities with multidisciplinary participation and integrated into networks which consider the health needs of the population and which allows assistance that is shared, participatory, humanized, and resolutive. These interventions need to facilitate the planning and development of educational actions where clients and their families are the focus of the health care [27].

The nursing activity in the hemotherapy sector can assume a social and health commitment with the purpose of caring for the population to improve their quality of life [3]. The educational practices have been expanded in the field of health and named in various forms that are related to the history of Education and Health and the way in which these practices have been appropriate. The educational action related to nursing care and the need to find academic environments that can facilitate this practice are important to our professional training.

Health professionals should emphasize the exchange of experiences and knowledge of clients and families. The nurse who is the primary caregiver should establish a dialogic and reflexive relationship reflecting an ongoing interactive process to improve health conditions [28].

Thus, the nurses' guidance is necessary for home care after transfusionand should include instructions on recognizing transfusion reactions that may be acute or immediate occurring during or up to 24 hours after the transfusion, or late or not immediate occurring after this period [29].

It is necessary for nurses to emphasize to clients, family members, and/or caregivers that these reactions can happen especially in the first 24 hours after the transfusion procedure. Should any adverse event occur, they must seek medical attention immediately.

Regarding the care and maintenance of life, the participants describe an improvement after transfusion, including well-being and disposition for life. They demonstrated the knowledge of the importance of this therapy in their speeches; however, in order to be healthy, favorable conditions and their maintenance are necessary for an improved quality of life.

To provide care for people in special situations such as fragility and lack of autonomy requires extended training or specialization.

This study developed a protocol for patients admitted to ambulatory hemotranfusion in order to provide the nursing team with clarity about the activities involved during and post transfusion. 


\section{Conclusions}

Analysis of sociodemographic data and health statistics of the patients receiving a blood transfusion at the University Hospital revealed the need to build an assistance protocol. This protocol will provide information about home self-care to patients. Nurses and other professionals should have a better understanding of their patients and socio-economic and cultural conditions, information, which may facilitate their relationship and possibly contribute to self-care.

Therefore, a better understanding of the individual patient's demographics on the part of the educator-counselor can stimulate subjects to actively participate in their self-care. The essential goal of nursing is to provide quality health care, a goal, which may be facilitated by recognizing that a patient is an individual with unique needs and values which must be treated integrally, without separating mind from body. A quality nursing care focused on self-care aims to improve the client's quality of life.

Thus, the nursing care provided during the transfusion procedure is aimed at immediate care; there is a need for health guidelines for these clients and their relatives regarding possible adverse events that may occur during and after treatment.

Hence, it is important that new research is carried out within the scope of nursing professionals and multi-professionals to improve the quality of life of patients and enlighten the conditions for their self-care at home.

\section{References}

[1] Portaria No 2.712 de 12 de novembro de 2013 (2013) Publicado no Diário Oficial da União no 221, de 13 de novembro de 2013, 106. http://bvsms.saude.gov.br/bvs/saudelegis/gm/2013/prt2712 12 11 2013.html

[2] Silva Junior, J.B. and Rattner, D. (2014) Segurança Transfusional: um método de Vigilância Sanitária para avaliação de riscos potenciais em serviços de hemoterapia. VigSanit Debate, 43-52. http://portal.anvisa.gov.br/documents/33840/2437178/Avalia\%C3\%A7\%C3\%A3o+ $\mathrm{de}+$ Riscos+Potenciais+em+Sangue/c827b3bb-1f87-4225-9758-725a876882f4

[3] Barbosa, S.M., Torres, C.A., Gubert, F. do A., Pinheiro, P.N. da C. and Vieira, N.F.C. (2011) Enfermagem e a prática hemoterápica no Brasil: Revisão integrativa. Acta Paulista de Enfermagem, 24, 132-136. https://doi.org/10.1590/s0103-21002011000100020

[4] Brum, D.E.L. (2011) Racionalizar a transfusão de hemocomponentes: benefícios a pacientes, instituições e operadoras de planos de saúde. Revista da AMRIGS, Porto Alegre, 55, 76-82.

[5] Conselho Federal de Enfermagem (BR) (2006) Resolução COFEN nº 306/2006. Brasília (DF). http://www.cofen.gov.br/

[6] Sullivan, M.T., Russel, C., Read, E.J. and Wallace, E.L. (2007) Blood Collection and Transfusion in the United States in 2001. Transfusion, 47, 385-394. https://doi.org/10.1111/j.1537-2995.2007.01128.x

[7] Murphy, G.J., Reeves, B.C. and Rogers, C.A. (2007) Increase Mortality, Postoperative Morbidity, and Cost after Red Blood Cell Transfusion in Patients Having Cardiac Surgery. Circulation, 116, 2544-2552. 
https://doi.org/10.1161/CIRCULATIONAHA.107.698977

[8] AABB, American Red Cross, America's Blood Centers, and the Armed Services Blood Program (2013) Circular of Information for the Use of Human Blood and Blood Components. https://www.aabb.org/tm/coi/Documents/coi1113.pdf

[9] Portaria $n^{\circ}$ 1353, de 13 de junho de 2011 (2011) Portaria $n^{\circ} 1353$, de 13 de junho de 2011-Anexo V da Portaria no 1353/2011. Anvisa Portal/Anvisa/Inicio/Sangue. http://bvsms.saude.gov.br/bvs/saudelegis/gm/2011/prt1353 $13 \quad 06 \quad 2011 . \mathrm{html}$

[10] Cata, J.P., Lasala, J., Pratt, G., Feng, L. and Shah, J.B. (2016) Association between Perioperative Blood Transfusions and Clinical Outcomes in Patients Undergoing Bladder Cancer Surgery: A Systematic Review and Meta-Analysis Study. Journal of Blood Transfusion, 2016, Article ID: 9876394.

https://doi.org/10.1155/2016/9876394

[11] Mattia, D. and Andrade, S.R. (2016) Nursing Care in Blood Transfusion: A Tool for Patient Monitoring. Texto \& Contexto-Enfermagem, 25, e2600015.

http://www.scielo.br/scielo.php?script=sci arttext\&pid=S0104-07072016000200308 \&lng=en

[12] Silva, I.J., Oliveira, M.F.V., Silva, S.E.D., Polaro, S.H.I., Radünz, V., Santos, E., Kotzias, A., et al. (2009) Cuidado, autocuidado e cuidadode si: Uma compreensão paradigmática para o cuidado de enfermagem. Revista da Escola de Enfermagem da USP, 43, 697-703.

http://www.scielo.br/scielo.php?script=sci arttext\&pid=S0080-62342009000300028 $\underline{\text { \&lng=en }}$ https://doi.org/10.1590/S0080-62342009000300028

[13] Bardin, L. (2011) Análise de conteúdo. Rego, L.A. and Pinheiro, A., Trads., Edições 70, Lisboa. (Obra original publicada em 1977)

[14] Ministério da Saúde, Instituto Nacional de Câncer José Alencar Gomes da Silva (INCA) (2015) Coordenação de Prevenção e Vigilância Estimativa 2016: Incidência de câncer no Brasil. Rio de Janeiro. http://www.inca.gov.br/estimativa/2016/estimativa-2016-v11.pdf

[15] Rodrigues, F.F.L., Santos, M.A., Teixeira, C.R.S., Gonela, J.T. and Zanetti, M.L. (2012) Relação entre conhecimento, atitude, escolaridade e tempo de doença em indivíduos com diabetes mellitus. Acta Paulista de Enfermagem, 25, 284-290.

http://www.scielo.br/pdf/ape/v25n2/a20v25n2.pdf https://doi.org/10.1590/S0103-21002012000200020

[16] Bird, G.T., Farquhar-Smith, P., Wigmore, P.T., Potter, M. and Gruber, P.C. (2012) Outcomes and Prognostic Factors in Patients with Haematological Malignancy Admitted to a Specialist Cancer Intensive Care Unit: A 5 yr Study. British Journal of Anaesthesia, 108, 452-459.

[17] Barbosa, S.F.C., Costa, C.A., Ferreira, L.S.C., Almeida, D.S., Azevedo, T.C.B., Lemos, J.A.R., et al. (2015) Aspectos epidemiológicos dos casos de leucemia e linfomas em jovens e adultos atendidos em hospital de referência para câncer em Belém, Estado do Pará, Amazônia, Brasil. Revista Pan-Amazônica de Saúde, 6, 43-50. https://doi.org/10.5123/s2176-62232015000300006 http://scielo.iec.pa.gov.br/scielo.php?script $=$ sci arttext\&pid $=S 2176-6223201500030$ 0006\&lng=pt

[18] Torres, S.V., Sbegue, A. and Costa, S.C. (2016) A Importância do diagnóstico precoce de câncer bucal em idosos. Sociedade Brasileira de Clínica Médica, 14, 57-62. http://docs.bvsalud.org/biblioref/2016/05/32/57-62.pdf

[19] Araújo, J.S. and Xavier, M.P. (2014) O conceito de saúde e os modelos de assistência: Considerações e perspectivas em mudança. Revista Saúde em Foco, 1, 
137-149.

http://webcache.googleusercontent.com/search?q=cache:http://www4.fsanet.com.br /revista/index.php/saudeemfoco/article/viewFile/326/382\&gws rd=cr\&ei=ycB-WJe GNMebwASnrrrwAg

[20] Terra, F.S., Costa, A.M.D.D., Damasceno, L.L., Lima, T.S., Filipini, C.B. and Leite, M.A.C. (2013) Avaliação da qualidade de vida de pacientes oncológicos submetidos à quimioterapia. Sociedade Brasileira de Clínica Médica, 11, 112-117 http://files.bvs.br/upload/S/1679-1010/2013/v11n2/a3564.pdf

[21] Bousso, R.S., Poles, K., Serafim, T.S. and Miranda, M.G. (2011) Crenças religiosas, doença e morte: Perspectiva da família na experiência de doença. Revista da Escola de Enfermagem da USP, 45, 397-403.

http://www.scielo.br/scielo.php?script=sci arttext\&pid=S0080-62342011000200014 \&lng=en https://doi.org/10.1590/S0080-62342011000200014

[22] Alves, R.F., Melo, M.O., Andrade, S.F.O., Fernandes, T.S., Gonçalves, D.L. and Freire, A.A. (2012) Qualidade de vida em pacientes oncológicos na assistência em casas de apoio. Aletheia, 38-39, 39-54.

http://pepsic.bvsalud.org/scielo.php?script=sci arttext\&pid=S1413-03942012000200 $\underline{004 \& \operatorname{lng}=\mathrm{pt}}$

[23] Constituição da República Federativa do Brasil (1988) Artigos 196. 1. http://conselho.saude.gov.br/web sus20anos/20anossus/legislacao/constituicaofeder al.pdf

[24] Orem, D.E. (2001) Nursing Concepts of Practice. Mosby.

[25] Freire, P. (2013) Pedagogia da autonomia: Saberes necessários a prática educativa. Paz e Terra, São Paulo.

[26] Fassarella, C.S., Pinto, V.A.E. and Alves, A.S. (2013) O enfermeiro como educador na reabilitação cardíaca dentro da estratégia saúde da família: Revisão da literatura. Revista Rede de Cuidados em Saúde, 7, 1-8 http://publicacoes.unigranrio.br/index.php/rcs/article/view/1903/903

[27] Ministério da Saúde (2015) Secretaria de Vigilância em Saúde. Secretaria de Atenção à Saúde. Política Nacional de Promoção da Saúde: PNPS: Revisão da Portaria MS/GM n 687, de 30 de março de 2006/Ministério da Saúde, Secretaria de Vigilância em Saúde, Secretaria de Atenção à Saúde. Ministério da Saúde, Brasília.

[28] Acioli, S., David, H.M.S.L. and Faria, M.G.A. (2012) Educação em saúde e a enfermagem em saúde coletiva: Reflexões sobre a prática. Revista Enfermagem UERJ, 20, 533-536. http://www.facenf.uerj.br/v20n4/v20n4a20.pdf

[29] Zago, M.A., Falcão, P.R. and Pasquini, R. (2013) Tratado de Hematologia. Atheneu, Rio de Janeiro. 
Submit or recommend next manuscript to SCIRP and we will provide best service for you:

Accepting pre-submission inquiries through Email, Facebook, LinkedIn, Twitter, etc. A wide selection of journals (inclusive of 9 subjects, more than 200 journals)

Providing 24-hour high-quality service

User-friendly online submission system

Fair and swift peer-review system

Efficient typesetting and proofreading procedure

Display of the result of downloads and visits, as well as the number of cited articles Maximum dissemination of your research work

Submit your manuscript at: http://papersubmission.scirp.org/

Or contact ojn@scirp.org 